Al-Azhar Bull. Sci. Vol. 19, No. 2 (Dec.): pp. 29-40, 2008.

\title{
STUDIES INCLUDING TOLERANCE, AFFINITY AND CAPACITY OF CERTAIN FUNGAL SPECIES FOR SOME TOXIC ELEMENTS IN AQUEOUS SOLUTION
}

A.S. ABDEL-RAZEK ${ }^{1}$; S.A. MAHMOUD ${ }^{1}$; H.H. EL-SHEIKH ${ }^{2}$; T.M. ABDELGHANY $^{2}$; M.S. MAHMOUD ${ }^{1}$

1. Hot Laboratories and Waste Management Center, Atomic Energy Authority.

2. Department of Botany \& Microbiology, Faculty of Science, Al-Azhar University.

\begin{abstract}
Some fungal species isolated from the soil of the radioactive repository site at Hot Laboratories Center were investigated for their tolerance, affinity and capacity towards different metal ions namely; Cerium Ce(III), Chromium $\mathrm{Cr}(\mathrm{VI})$, Cobalt $\mathrm{Co}(\mathrm{II})$, and Cadmium $\mathrm{Cd}(\mathrm{II})$. They were identified as Aspergillus tamarii, Aspergillus niger, Penicellium chrysogenum, Cunninghamella elegans and Rhizopus stolonifer. The obtained results showed that, the lowest concentration of metal ion could be tolerated by fungal species was 50ppm for $\mathrm{Co}$ (II) \& $\mathrm{Cd}(\mathrm{II})$, while the highest one was $2000 \mathrm{ppm}$ for $\mathrm{Cr}$ (VI) \& $\mathrm{Ce}(\mathrm{III})$. Also, tolerance towards mixture of ions was varied among the fungi under study. The affinity of the fungal species of study for metal ions under investigation was found to have the following order; $\mathrm{Ce}(\mathrm{III})>\mathrm{Cd}(\mathrm{II})>\mathrm{Co}(\mathrm{II})>\mathrm{Cr}(\mathrm{VI})$. Results showed that Aspergillus niger had high capacity for $\mathrm{Ce}$ (III) ions uptake, while Cunninghamella elegans had high capacity for $\mathrm{Co}$ (II) ions uptake. The effects of chemical and physical pretreatments of fungal biomass on the uptake capacity were studied using Aspergillus niger \& $\mathrm{Ce}(\mathrm{III})$. The uptake of $\mathrm{Ce}(\mathrm{III})$ by Aspergillus niger was studied using different concentrations of $\mathrm{Ce}$ (III). It was found that one gram dry weight of Aspergillus niger could accumulate $285.7 \pm 16.9,571.43 \pm 23.9$ and $1142.86 \pm 33.8 \mathrm{mg}$ of Ce(III) from 50, 100 and 200 ppm solutions, respectively.
\end{abstract}

\section{Introduction}

The release of large quantities of heavy metals from industries into the environment has resulted in a number of environmental problems. Pollution of the natural environment by heavy metals has become a serious problem in some industrial countries (Inthorn et al., 1996). Low level heavy metal pollution of rivers, lakes and oceans environments is now wide spread, and because heavy metals are concentrated in the food chain, this cause damage to aquatic ecosystems as well as being danger to human health (Nagase et al., 1997).

Biosorption of heavy metals from aqueous solutions is a relatively new technology for the treatment of industrial wastewater (Volesky, 1990). Also, it's defined as a process that utilizes inexpensive dead biomass to sequester toxic heavy metals and to remove contaminants from industrial effluents (Ting et al., 1991 and 
Singh et al., 1998). The use of biological materials for heavy metal removal and recovery technologies had gained important credibility during recent years, because of the good performance, low cost of the complexing material and the natural affinity of biological sources.

Fungi cell walls contain large quantity of polysaccharides and proteins, which offer many functional groups (such as carboxyl, hydroxyl, sulfate, phosphate and amino groups) for binding metal ions (Bayramoglu et al., 2003 and Zhou et al., 2004). The cell surfaces of microorganisms are negatively charged owing to the presence of various anionic structures. This gives microorganisms an ability to bind metal cations (Chen \& Hao, 1998). The mode of interaction between metal species and microbial cell components may be simple adsorption, ion exchange, electrostatic interaction, complexation, precipitation, and crystallization (Crist et al., 1994). Biological process for removal of metal ions from solution could be divided into three categories: biosorption of metal ions onto the surface of microorganisms (Ozdemir et al., 2003 and Liu et al., 2004), chemical transformation of metal ions and intracellular uptake of metal ions by microorganisms. The later two processes needed viable microorganisms and were called bioaccumulation (Dursun et al., 2003 and Uslu et al., 2003).

A number of mechanisms by which microorganisms tolerated and removed heavy metals had been proposed. Microorganisms modulated metal toxicity by maintaining a low intracellular concentration of toxic metals via (i) extracellular accumulation / precipitation; (ii) cell-surface sorption or complexation (adsorption to the cell surface) and (iii) intracellular accumulation (accumulation in the precellular or endocellular regions of the cell) (Muraleedharan et al., 1991; Gadd, 1993 and Bridge et al., 1999).

Heat inactivation of biomass could produce additional binding sites via denaturation of proteins on cell wall structures (Tuzun et al., 2005 and Hafez et al., 1997). Also, alkali treatment could cause hydrolysis of protein and deacetylation of chitin into chitosan. It had been reported that the performance of a microbial biomass depended on its surface properties. It was found that, the pretreatment of Aspergillus. niger by $\mathrm{NaOH}$ resulted in a significant improvement in metal ions removal in comparison with un-pretreated biomass (Kapoor and Viraraghavan, 1998).

The $\mathrm{Cr}(\mathrm{VI})$ sorption ability of powdered biomass of Rhizopus nigricans was investigated by Bai and Abraham, (2001). The influence of solution $\mathrm{pH}$, agitation, 
$\mathrm{Cr}(\mathrm{VI})$ concentration, biomass dosage, contact time, temperature and biomass particle size was studied. The results cleared that, the optimum $\mathrm{pH}$ for biosorption of $\mathrm{Cr}(\mathrm{VI})$ was found to be 2.0. Higher adsorption percentage was noted at lower initial concentrations of $\mathrm{Cr}(\mathrm{VI})$ ions, while adsorption capacity of the biomass increased with increasing concentration of ions. Moreover the adsorption capacity increased with increase in temperature and agitation speed and the optimum were determined as $45^{\circ} \mathrm{C}$ at $120 \mathrm{rpm}$.

The present study was conducted to investigate the tolerance, affinity and capacity of certain fungal species namely Aspergillus tamarii, Aspergillus niger, penicillium chrysogenum, Cunninghamella elegans and Rhizopus stolonifer for different metal ions $(\mathrm{Ce}, \mathrm{Cd}, \mathrm{Cr}$ and $\mathrm{Co}$ ). The effect of pretreatment of fungal biomass on the uptake of metal ions was investigated using Aspergillus niger and $\mathrm{Ce}(\mathrm{III})$ ions. Also, the uptake of $\mathrm{Ce}(\mathrm{III})$ by Aspergillus niger using different concentrations of $\mathrm{Ce}(\mathrm{III})$ was studied.

\section{Materials and methods:-}

Chemicals: All chemicals used were of analytical purity grades. Solutions of $\mathrm{Ce}(\mathrm{III}), \mathrm{Co}(\mathrm{II}), \mathrm{Cr}(\mathrm{VI})$ and $\mathrm{Cd}(\mathrm{II})$ were prepared as stock solutions and other concentrations were obtained by dilution. Solutions of hydrochloric acid and sodium hydroxide with different concentrations were used to adjust the $\mathrm{pH}$ to the desired values.

Fungal isolates: Five fungal species were isolated from soils of repository site at Waste Management Facility, Hot Laboratory Center, Atomic Energy Authority, Egypt. The fungal species were isolated using dilution plate method, quadrant type (Benson, 1985). The isolated fungi were identified in The Regional Center for Mycology and Biotechnology - Al-Azhar University as; Aspergillus tamarii, Aspergillus niger, penicillium chrysogenum, Cunninghamella elegans and Rhizopus stolonifer according to (Pit, 1979; Domsch et al., 1993 and Samson et al., 2000).

Tolerance experiments: The growth of Aspergillus tamarii, Aspergillus niger, penicillium chrysogenum, Cunninghamella elegans and Rhizopus stolonifer on Sabouraud's dextrose agar had been studied in the presence of various concentrations of $\mathrm{Ce}(\mathrm{III}), \mathrm{Cr}(\mathrm{VI}), \mathrm{Cd}(\mathrm{II}), \mathrm{Co}(\mathrm{II})$ and mixed ions concentrations. The concentrations ranged from 200 to $2000 \mathrm{ppm}$ for $\mathrm{Ce}(\mathrm{III})$ and $\mathrm{Cr}(\mathrm{VI})$, while the concentrations of $\mathrm{Cd}$ (II) or $\mathrm{Co}$ (II) were ranged from $50-1000 \mathrm{ppm}$. The mixed ions concentrations ranged from 200-600 ppm with equal ratio. The incubation temperature was adjusted to $28^{\circ} \mathrm{C}$ and the growth was observed after $3-15$ days. 
Biomass pretreatment: The fungal biomass of Aspergillus niger was subjected to chemical and physical pretreatments. Chemical treatments were conducted by washing for 15 min with: a) $0.025,0.05 \& 0.1 \mathrm{~N} \mathrm{NaOH}$; b) $0.125,0.25 \& 0.5 \%$ glutraldehyde; c) $0.25,0.5 \& 1.0 \%$ anhydrous $\mathrm{CaCl}_{2}$. On the other hand, physical pretreatments were carried out by: a) boiling in bidistilled water for $15 \mathrm{~min}$; b) autoclaving for $15 \mathrm{~min}$ at $121^{\circ} \mathrm{C} \mathrm{\&} 1.5 \mathrm{psi}$; c) washing with bidistilled water. After the pretreatments the biomass was washed with deionized water until the $\mathrm{pH}$ of the washing solution was close to $\mathrm{pH} 6.8-7.2$. The biomass had been dried at $60^{\circ} \mathrm{C}$ for $24 \mathrm{~h}$ to get the dry weight.

Screening \& Uptake experiments: In batch experiment, 0.5 gram of fungal biomass was immersed in $50 \mathrm{ml}$ of metal ion solution. The $\mathrm{pH}$ of the solutions was adjusted to $4.5-5.0 \pm 0.2$ except for $\mathrm{Cr}(\mathrm{VI})$ the $\mathrm{pH}$ was adjusted to $2.0 \pm 0.2$. The temperature was adjusted at $25 \pm 3^{\circ} \mathrm{C}$ and stirring was $250 \mathrm{rpm}$. Samples were taken at different contact times and the amount of the ion accumulated on fungal biomass was estimated. The quantitative determination of chromium, cobalt and cadmium were carried out using atomic absorption spectrophotometer (Buck) model 210 VGP, and measurement of cerium was carried out using UV-spectrophotometer Shimadzu -160 .

Calculations: The concentration of metal ion solution at different contact times (t) with fungal biomass $\left(\mathrm{C}_{\mathrm{t}}\right)$ was given directly by atomic absorption spectrophotometer, while for UV- spectrophotometer $C_{t}=A_{t} X k$; where $\quad A_{t}$ is absorbance at time $(\mathrm{t}), \mathrm{k}$ is a constant. The uptake amount in $(\mathrm{mg})$ of metal ion at time ( $\mathrm{t}$ ) by $0.5 \mathrm{~g}$ wet weight of fungal biomass $\left(\mathrm{Q}_{\mathrm{t}}\right)=\mathrm{C}_{0}-\mathrm{C}_{\mathrm{t}}$, where $\mathrm{C}_{0}$ is the initial concentration. The uptake percent of metal ion at different contact times with fungal biomass $=\mathrm{Q}_{\mathrm{t}} / \mathrm{C}_{0} \mathrm{X} 100$. The uptake amount in $(\mathrm{mg})$ of studied ion at time $(\mathrm{t})$ by $1 \mathrm{~g}$ dry weight of fungal biomass $(\mathrm{Q})=\mathrm{Qt} /$ dry wt.

\section{Result and discussion:-}

\section{1- Tolerance tests}

The five isolated fungal species exhibited different resistances (Minimum Inhibitory concentration MIC values) towards the metal ions under test $\mathrm{Ce}(\mathrm{III})$, $\mathrm{Cr}(\mathrm{VI}), \mathrm{Cd}(\mathrm{II})$ and $\mathrm{Co}(\mathrm{II})$. The highest MIC value was observed for $\mathrm{Ce}(\mathrm{III}) \& \mathrm{Cr}(\mathrm{VI})$ (>2000ppm) and the lowest MIC value was for $\mathrm{Cd}(\mathrm{II}) \& \mathrm{Co}(\mathrm{II})$ (>50ppm). Also, for mixture of the ions with concentration ranged from $(200-600 \mathrm{ppm})$ in equal ratio, the tolerances varied. It was found that Rhizopus stolonifer failed to tolerate any of 
mixture concentration, while Penicillium chrysogenum and Aspergillus niger could tolerate all mixture concentrations (i.e. $\mathrm{MIC}_{\mathrm{mix}}>600 \mathrm{ppm}$ ). For Cunninghamella elegans and Aspergillus tamarii $\mathrm{MIC}_{\text {mix }}>400 \& 200$ ppm, respectively, results given in Table (1) \& Fig.(1). It was also found that the period needed for growth increased with the increase in the metal ion concentration in growth media.

Table (1): MIC of the studied fungal species toward different metal ions

\begin{tabular}{|c|c|c|c|c|c|}
\hline \multirow{2}{*}{ FUNGM } & A. tam. & A. nig. & Pen. chry. & Cun. ele. & Rhi. sto. \\
\cline { 2 - 6 } & $\begin{array}{c}\text { MIC } \\
(\mathrm{ppm})\end{array}$ & $\begin{array}{c}\text { MIC } \\
(\mathrm{ppm})\end{array}$ & $\begin{array}{c}\text { MIC } \\
(\mathrm{ppm})\end{array}$ & $\begin{array}{c}\text { MIC } \\
(\mathrm{ppm})\end{array}$ & $\begin{array}{c}\text { MIC } \\
(\mathrm{ppm})\end{array}$ \\
\hline $\mathrm{Ce}(\mathrm{III})$ & $>600$ & $>2000$ & $>2000$ & $>2000$ & $>2000$ \\
\hline $\mathrm{Cr}(\mathrm{VI})$ & $>2000$ & $>2000$ & $>2000$ & $>2000$ & $>2000$ \\
\hline $\mathrm{Cd}(\mathrm{II})$ & $>50$ & $>50$ & $>1000$ & $>1000$ & $>200$ \\
\hline $\mathrm{Co}(\mathrm{II})$ & $>600$ & $>200$ & $>400$ & $>100$ & $>50$ \\
\hline $\begin{array}{c}\text { Mixed ions } \\
\text { (equal ratio) }\end{array}$ & $>200$ & $>600$ & $>600$ & $>400$ & 0 \\
\hline
\end{tabular}

The high MIC value could be explained by; low toxicity of such metal ions, or addition chelation co-precipitation, or metabolic active uptake mechanisms. Also, this depends on the detoxification mechanism of each fungal species (Zafar et al., 2007 and Hildebrandt et al., 2007). This indicated that metal- resistance phenotypes were well-distributed among the representative fungal genera (Kapoor et al., 1999 and Say et al., 2003).

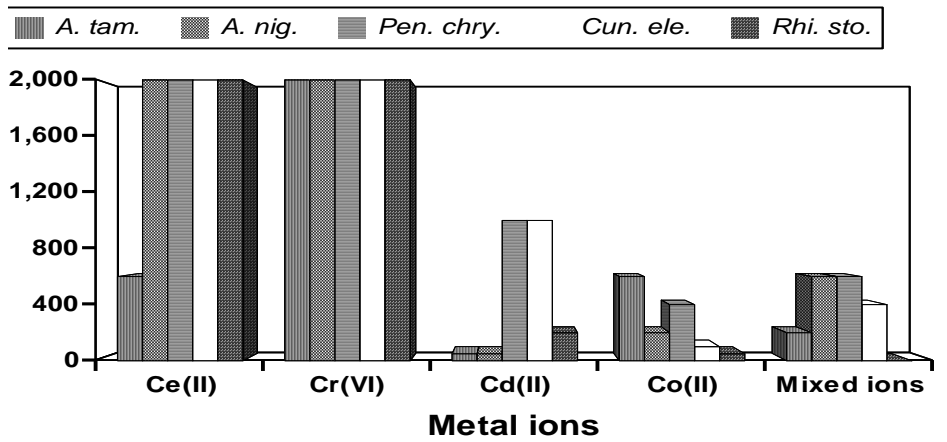

Fig.(1): MIC values of the studied fungal species toward different metal ions 
Also, results revealed that fungal biomass obtained from metal-resistant fungi had the same capacity for metal ion uptake as the fungal biomass that wasn't exposed to high metal ion concentrations. This could be explain that the capability of fungal species to live on high metal ion concentrations was depending on detoxification mechanisms, while the absorption capacity depended (mainly) on cell wall composition (Bayramoglu et al., 2003 and Zhou et al., 2004). Fungi could tolerate and detoxify metals by several mechanisms including; valence transformation, extra and intra-cellular precipitation and metabolic active uptake (Gadd, 1993 and Zafar et al., 2007).

\section{2- Screening test:}

Screening of the studied fungal species for their affinity and capacity towards metal ions under investigation (Ce(III), $\mathrm{Cr}(\mathrm{VI}), \mathrm{Cd}(\mathrm{II})$ and $\mathrm{Co}(\mathrm{II})$ ) showed differences in the affinity and capacity of the fungal species under study towards metal ions.

Aspergillus niger showed highest accumulation capacity for $\quad \mathrm{Ce}(\mathrm{III})$ ions; while Cunninghamella elegans exhibited high capacity for most of the metal ions under study $\mathrm{Cd}(\mathrm{II}), \mathrm{Co}(\mathrm{II}) \& \mathrm{Cr}(\mathrm{VI})$. These differences in accumulation capacities could be attributed to wide variation in the chemical composition of their cell walls and the chemical properties of the metal ions (Gadd, 1990).

Results given in Fig.(2) indicated that the metal ions under study could be arranged according to their absorption affinity is $\mathrm{Ce}$ (III) $>\mathrm{Cd}(\mathrm{II})>\mathrm{Co}$ (II) $>\mathrm{Cr}$ (VI) Also, results revealed that the capacity of the fungal species differed from one metal ion to another. The difference in absorption capacities depend on many factors such as; cell wall composition of the fungal species, the chemistry of the metal ions and the toxicity.

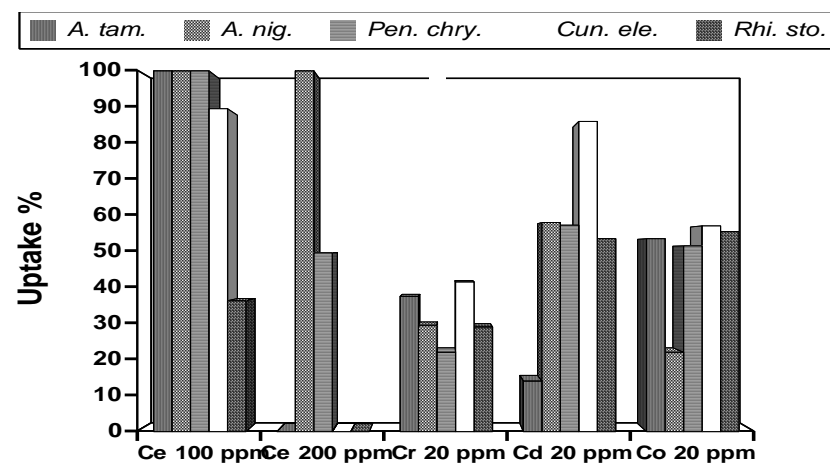

Different metal ions

Fig. (2): The uptake percent of different metal ions by the studied fungal species. 
Biosorption is relatively rapid and can be reversible. It involves a physicochemical interaction between the metal and functional groups such as ketones, aldehydes and carboxyls present on the microorganism's cell surface. It is often followed by a slower metal binding process in which additional metal ion is bound, often irreversibly. This slow phase of metal uptake can be attributed to a number of mechanisms, including covalent bonding, surface precipitation, redox reactions, crystallization on the cell surface or, most often, diffusion into the cell interior and binding to proteins and other intracellular sites (Ozer et al., 1999).

\section{3- Pretreatment test:}

Obtained results in Fig.(3) indicated that biosorption of $\mathrm{Ce}(\mathrm{III})$ by pretreated Aspergillus niger either increased or decreased depending on the pretreatment method. The order of maximum uptake of $\mathrm{Ce}(\mathrm{III})$ by A. niger is as follows; pretreated with autoclaving $\geq$ washing with distilled water $>$ washing with $0.25 \%$ glutraldehyde > washing with $0.05 \mathrm{~N} \mathrm{NaOH}>$ washing with $0.5 \%$ anhy. $\mathrm{CaCl} 2>$ Boiling. An increase in biosorption of cerium ions as a result of pretreatment could be due to an exposure of active metal binding sites embedded in the cell wall or chemical modifications of the cell wall components. The increase in metal biosorption after pretreating the fungal biomass could be attributed to the removal of surface impurities and to the exposure of available binding sites for metal biosorption (Huang \& Huang, 1996).

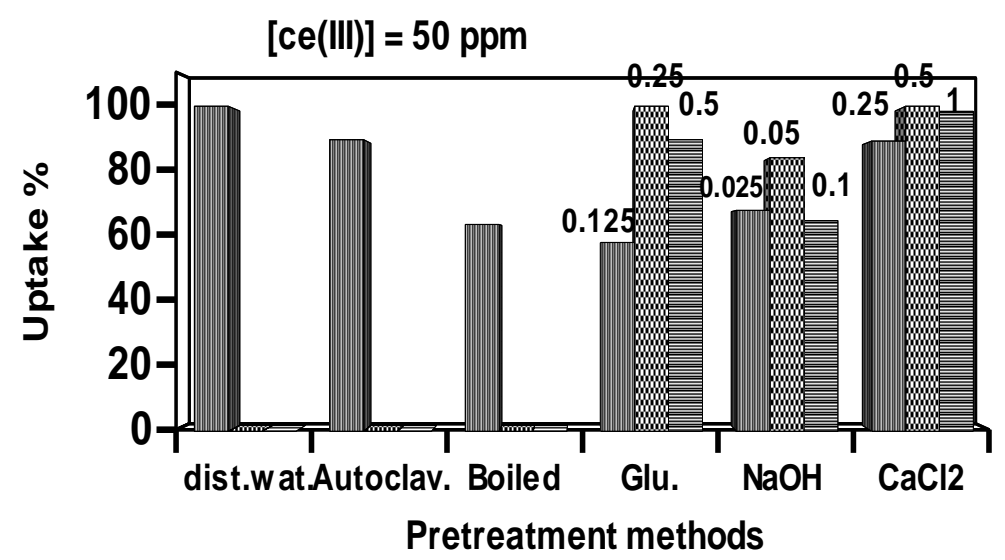

Fig. (3): The uptake percent of Ce (III) by physical and chemical pretreated Aspergillus niger after two hours of contact. 
Pretreatment with autoclaving resulted in an improvement in $\mathrm{Ce}(\mathrm{III})$ biosorption. Glutraldehyde pretreatment reduced biosorption of $\mathrm{Ce}$ (III) to a certain extent while, sodium hydroxide, calcium chloride and boiling pretreatment significantly reduced biosorption of $\mathrm{Ce}(\mathrm{III})$. The reduction of biosorption capacity in glutraldehyde, sodium hydroxide, calcium chloride and boiling pretreatment may be attributed to the loss of some active groups.

It was found that Mucor rouxii biomass pretreated by autoclaving reduced the biosorption of heavy metals (Yan and Viraraghavan, 2000). In the same way Kapoor \& Viraraghavan, (1998) reported that $A$. versicolor pretreated by autoclaving reduced the biosorption of cadmium, copper, and nickel. Heat and autoclaving pretreatment increased the biosorption capacity of microbial biomass due to the exposure of latent binding sites after pretreatment (Galun et al., 1987).

It was found that $\mathrm{Pb}^{2+}$ biosorption by Saccharomyces uvarum was more efficient after sodium hydroxide treatment due to unmasking of some cellular groups which can't participate in the sorption process without treatment with alkali (Ashkenazy et al. 1997, Yan and Viraraghavan, 2000). In contrast, (Kapoor \& Viraraghavan, 1998) reported that in nickel biosorption by sodium hydroxide pretreatment there was an approximately $45 \%$ reduction in comparison with live cells. As a result of sodium hydroxide treatment, the number of protein amino groups that can be engaged in metallic ion binding markedly decreased. Deproteination should, theoretically, reduce metal retention. Since the cell wall composition can be characteristic of the fungal species, we could say that this conflict is normal.

Gluteraldehyde is a cross-linking reagent with multifunctional groups. According to (Jianlong, 2002) gluteraldehyde pretreated Saccharomyces cerevisiae biomass retains almost all its original biosorption capacity. In contrast in our study, gluteraldehyde pretreatment reduce $\mathrm{Ce}$ (III) biosorption of fungal biomass, according to (Yan and Viraraghavan, 2000) the difference in results after a specific pretreatment may be attributed to the different strains of fungi.

\section{4- Ce(III) uptake:}

Aspergillus niger had the highest biosorption capacity for cerium ions among the fungal species under study. The increase in Ce(III) (metal ion) concentration results in an increase in the amount of metal ion accumulation. At low metal ion concentrations of $50-100 \mathrm{ppm}$, the total amount (100\%) of metal ion were found to be accumulated within 2 min while, at high metal ion concentration of 200 ppm, 
$50 \%$ of metal ion was accumulated after 5 min of contact and the remaining amount was accumulated within the rest of the two hours and the results are given in Fig.(4). This could be explained that with a fixed adsorbent weight, the metal ion accumulation increased with the increase of metal ion concentration until reach saturation of active absorption sites on the fungal cell walls (Ilhan et al., 2004).

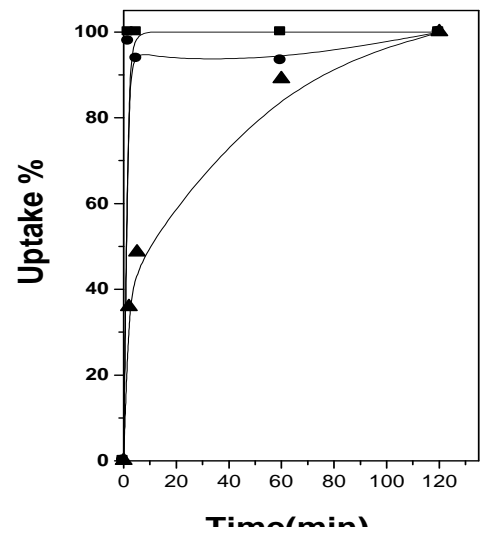

Fig.(4): The uptake percent of $\mathrm{Ce}(\mathrm{III})$ by Aspergillus niger from different $\mathrm{Ce}(\mathrm{III})$ concentrations at different contact times.

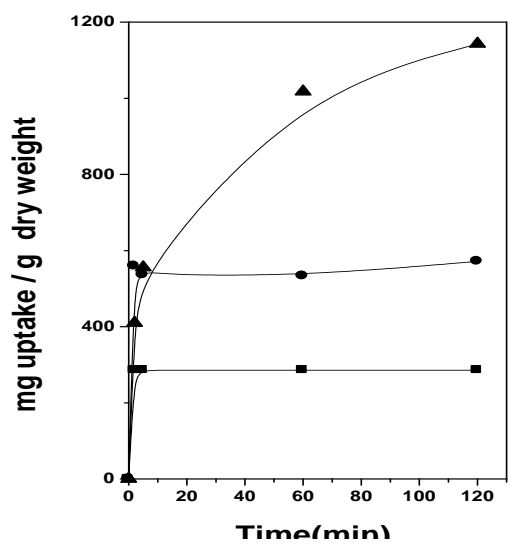

Fig.(5): The amount absorbed of $\mathrm{Ce}(\mathrm{III})$ in(mg)/g dry weight of Aspergillus niger, from different $\mathrm{Ce}(\mathrm{III})$ concentrations, at different contact times.

The uptake of $\mathrm{Ce}$ (III) by Aspergillus niger was studied using different concentrations of $\mathrm{Ce}(\mathrm{III})$. It was found that one gram dry weight of Aspergillus niger could accumulate $285.7 \pm 16.9,571.43 \pm 23.9$ and $1142.86 \pm 33.8 \mathrm{mg}$ of $\mathrm{Ce}$ (III) from 50, 100 and 200 ppm solutions, respectively, results given in Fig.(5).

\section{References}

1. ASHKENAZY, R.; GOTTLIEB, L. AND YANNAI, S., (1997). "Characterization of acetone washed yeast biomass functional groups involved in $\mathrm{Pb}^{2+}$ biosorption." Biotechnol. Bioeng. 55: 1-10.

2. BAI, S.R. AND ABRAHAM, E.T. (2001). "Biosorption of $\mathrm{Cr}(\mathrm{VI})$ from aqueous solution by Rhizopus nigricans." Bioresour. Technol. $79: 73-81$. 
3. BAYRAMOGLU, G. ; BEKTAS, S. AND ARICA, M.Y., (2003). "Biosorption of heavy metal ions on immobilized white-rot fungus Trametes versicolor." J. Hazard. Mater. 101: 285.

4. BENSON, H.J., (1985). "Microbiological Applications." WM.C. Brown Publisher, Dubque, Lowa, USA. Pp. $82-88$.

5. BRIDGE, T.A.M.; WHITE, C. AND GADD, G.M., (1999). "Exracellular metal " Microbiol., 145: 2987-2995.

6. CHEN, J.M. AND HAO, O.J., (1998). "Microbial chromium (VI) reduction" Crit. Rev. Environ. Sci. Technol., 28: 219-251.

7. CRIST, R.H.; MARTIN, J.R.; CARR, D.; WATSON, J.R. AND CLARKE, H.J. (1994). "Interaction of metals and protons with algae. 4. Ion exchange vs adsorption models and a reassessment of Scatchard plots; ion-exchange rates and equilibrium compared with calcium alginate." Environ. Sci. Technol. 28: 1859-66.

8. DOMSCH, K.H.; GAMS,W. AND ANDERSON, T.H.,(1993). "Compendium Of Soil Fungi".

9. DURSUN, A.Y.; USLU, G.; CUCI, Y. AND AKSU, Z., (2003). "Bioaccumulation of copper (II), lead (II) and chromium (VI) by growing Aspergillus niger." Process Biochem. 38: $1647-1651$.

10. GADD, G.M., (1990). "Heavy metal accumulation by bacteria and other microorganisms." Experientia 46: 834-840.

11. GADD, G.M., (1993). "Interaction of fungi with toxic metals." New Phytol. 124: 25-60.

12. GALUN, M.; GALUN, E. AND SIEGEL, B.Z., (1987). "Removal of metal ions from aqueous solutions by Penicillium biomass: Kinetic and Uptake Parameters." Water, Air, and Soil Pollution 33: 359-371.

13. HAFEZ, N. ; ABDEL-RAZEK, A.S. \& HAFEZ, M.B. (1997). "Accumulation of some heavy metals on Aspergillus flavus." J. Chem.Tech. Biotech. 68: 19-22.

14. HILDEBRANDT, U.; REGVAR, M. AND BOTHE, H. (2007). "Arbuscular mycorrhiza and heavy metal tolerance. "Phytochemistry 68:139-146.

15. HUANG, C. AND HUANG, C.P., (1996). "Application of Aspergillus oryzae and Rhizopus oryzae for $\mathrm{Cu}(\mathrm{II})$ removal." Water Research 30: 1985-1990.

16. ILHAN, S.; NOURBAKHSH, M.N.; KILICARSLAN, S. AND OZDAG, H., (2004). "Removal of chromium, lead and copper ions from industrial waste waters by Staphylococcus saprophyticus." Turkish J. Elect. Biotechnol. 2: 50 - 57.

17. INTHORN, D.; NAGASE, H.; ISAJI, Y; HIRATA, K. AND MIYAMOTO, K., (1996). "Removal of cadmium from aqueous solutions by the filamentous cyanobacteium Tolypothrix tenuis " J. Fermentation and Bioeng., 82(6): 580-584.

18. JIANLONG W., (2002) "Biosorption of copper (II) by chemically modified biomass of Saccharomyces cerevisiae." Process Biochemistry 37: 847-850.

19. KAPOOR, A. AND VIRARAGHAVAN, T., (1998). "Biosorption of heavy metals on Aspergillus niger: Effect of pretreatment." Bioresour. Technol. 63: 109-113.

20. KAPOOR, A.; VIRARAGHAVAN, T. AND CULLIMORE, D.R., (1999). "Removal of heavy metals using the fungus Aspergillus niger." Bioresour. Technol. 70: 95-104. 
21. LIU, H.; CHEN, B.; LAN, Y. AND CHENG, Y., (2004). "Biosorption of Zn(II) and $\mathrm{Cu}$ (II) by the indigenous Thiobacillus thiooxidans." J. Chem. Eng. 97 : 195-201.

22. MURALEEDHARAN, T.R.; LYENGAR, L. AND VENKOBACHAR, C., (1991). "Biosorption: an attractive alternative for metal removal and recovery" Curr. Sci., 61: 379-85.

23. NAGASE, H.; INTHORN, D.; ISAJI, Y; ODA, A.; HIRATA, K. AND MIYAMOTO, K., (1997). "Selective cadmium removal from hard Wat. using NaOH-treated cells of the cyanobacterium Tolypothrix tenuis" J. Fermentation and Bioeng., 84(2): 580 - 584.

24. OZDEMIR, G.; OZTURK, T.; CEYHAN, N.; ISLER, R. AND COSAR, T., (2003). "Heavy metal biosorption by biomass of Ochrobactrum anthropi producing exopolysaccharide in activated sludge." Bioresour. Technol. 90: 71-74.

25. OZER, A.; OZER, D.; DURSUN, G. AND BULAK, S., (1999). "Cadmium (II) adsorption on Cladophora crispata in batch stirred reactors in series." Waste Manage. 19: 233-240.

26. PIT, J.I. (1979) "The genus Penicillium and its teleomorphic states of Eupenicillium and Talaromyces." Academic press, London, 643pp.

27. SAMSON, R.A.; HOEKSTRA, E.S. AND FRISVAD, J.C., (2000): Introduction To Food- And Airborne Fungi.

28. SAY, R.; YILMAZ, N. AND DENIZLI, A., (2003). "Removal of $\mathrm{Cr}(\mathrm{VI})$ ions from synthetic solutions by the fungus Penicillium canescens." Eur. J. Min. Proc. Environ. Prot. 3: $36-41$.

29. SINGH, S.; PRADHAN, S. AND RAI, L.C., (1998). "Comparative assessment of $\mathrm{Fe}^{3+}$ and $\mathrm{Cu}^{2+}$ biosorption by field and laboratory-grown Microcystis." Process Biochem. 33 : 495-504.

30. TING, Y.P.; LAWSON, F. AND PRINCE, I.G., (1991). "Uptake of cadmium and zinc by the alga Chlorella vulgaris: II. Multi-ion situation." Biotechnol. Bioeng. 37 : 445-455.

31. TUZUN, I.; BAYRAMOGLU, G.; YALCIN, E.; BASARAN, G.; CELIK, G. AND ARICA, M.Y., (2005). "Equilibrium and kinetic studies on biosorption of $\mathrm{Hg}(\mathrm{II}), \mathrm{Cd}(\mathrm{II})$ and $\mathrm{Pb}(\mathrm{II})$ ions onto microalgae Chlamydomonas reinhardtii." J. Environ. Manag. 77 : 85

32. USLU, G.; DURSUN, A.Y.; EKIZ, H.I. AND AKSU, Z., (2003). "The effect of Cd(II), $\mathrm{Pb}$ (II) and $\mathrm{Cu}(\mathrm{II})$ ions on the growth and bioaccumulation properties of Rhizopus arrhizus." Process Biochem. 39: 105-110.

33. VOLESKY, B., (1990). "Biosorption by Fungal Biomass" In: Volesky B. ed. Biosorption of Heavy Metals. CRC Press, Boca Raton, Florida p. 139-171.

34. YAN, G.Y. AND VIRARAGHAVAN, T., (2000) "Effect of pretreatment on the bioadsorption of heavy metals on Mucor rouxii." Water SA 26:119-123.

35. ZAFAR, S.; AQIL, F. AND AHMAD, I., (2007). "Metal tolerance and biosorption potential of filamentous fungi isolated from metal contaminated agricultural soil." Bioresour. Technol. 98: 2557-2561.

36. ZHOU, D.; ZHANG, L.; ZHOU, J. AND GUO, S., (2004). "Cellulose/chitin beads for adsorption of heavy metals in aqueous solution." Water Res. 38: 2643-2650. 


\section{الملخص العربي}

تناولت تلك الدراسـة عزل عدد من الفطريات من التربـة الموجودة بمقابر النفايات المشعة بمركز Aspergillus tamarii, Aspergillus niger, Penicellium المعامل الحارة وقد تم تعريفها كالأتي؛ chrysogenum, Cunninghamella elegans and Rhizopus stolonifer. الفطريـات على النمو في وجود تركيزات مختلفة مـن العناصر تحت الدراسـة (سبريوم - كروم -كويالت وكادميوم) وأيضاً القدرة على النمو فى وجود خليط من هذه العناصر • وجد أن أقل تركيز يمكن للفطريات

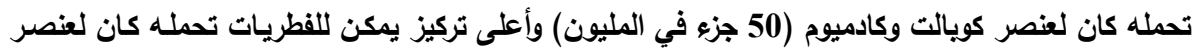

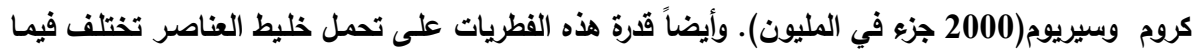
بينها. وجد أن قابلية الفطريات لامتصاص العناصر تحت الاراسة تأخذ الترتيب الأتي؛ سيريوم > كادئ كادميوم

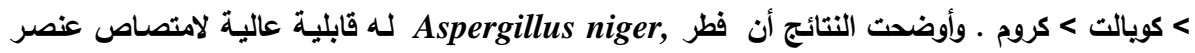
سيريوم و أن فطر Cunninghamella elegans له قابلية عالية لامتصاص عنصر كويالت. وتمت

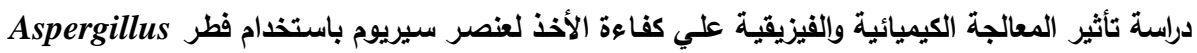
الم . niger,

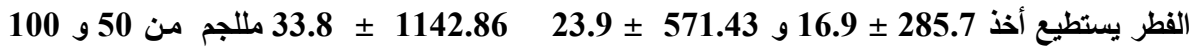
و 200 جزع في المليون من محلول العنصر على الترتيب. 